DOI: https://doi.org/10.24127/ajpm.v10i2.3450

\title{
ANALISIS PROSES TERJADINYA PENALARAN REVERSIBEL UNTUK MASALAH INVERS
}

\author{
Muhammad Muzaini ${ }^{1}$, Muhammad Ikram $^{2 *}$, Sirajuddin $^{3}$ \\ $1,2^{*}$ Universitas Cokroaminoto Palopo, Palopo, Indonesia \\ ${ }^{3}$ Universitas Muhammadiyah Makassar, Makassar, Indonesia \\ * Jalan Sungai Pareman Kel. Sabbangparu, 91913, Palopo, Indonesia \\ E-mail: $\quad$ muhammadmuzaini@uncp.ac.id ${ }^{1)}$ \\ muhammad.ikram@uncp.ac.id $^{2 *)}$ \\ sirajuddin@unismuh.ac.id ${ }^{3)}$
}

Received 04 January 2021; Received in revised form 14 June 2021; Accepted 29 June 2021

\begin{abstract}
Abstrak
Tujuan utama dari penelitian ini yaitu untuk menyelidiki proses terjadinya penalaran reversibel mahasiswa untuk masalah invers. Metode penelitian yang digunakan untuk mengungkapkan penalaran reversibel menggunakan metode penelitian kualitatif dengan pendekatan studi kasus. Pengambilan sampel dilakukan dengan menggunakan teknik purposive sampling di mana sampel penelitian dipilih berdasarkan kriteria penalaran reversibel. Pengambilan data dalam penelitian ini menggunakan hasil karya matematika mahasiswa, berpikir keras, wawancara, dan komponen yang menyebabkan penalaran reversibel. Hasil penelitian menunjukkan bahwa proses terjadinya penalaran riversibel diawali dengan adanya hambatan yang menyebabkan partisipan tidak mampu melanjutkan proses penyelesaian, sehingga terjadi proses metakognisi dengan menganalisa kembali masalah secara analitik dan mengembangkan strategi heuristik lainnya. Partisipan menunjukkan perubahan sudut pandang di mana ia awalnya memaknai invers sebagai tindakan menukar variabel independen dan dependen, dan beralih dengan memaknai invers sebagai kebalikan dari proses fungsi yang melibatkan analogi dan representasi gambar. Kontribusi penelitian ini yaitu memberikan pengetahuan bahwa penalaran reversibel dapat terjadi dalam memahami dan menyelesaikan masalah matematika pada materi invers.
\end{abstract}

Kata Kunci: Analitik; intuitif; masalah invers; metakognisi; reversibel.

\begin{abstract}
The main objective of this study is toilnvestigate the process of reversible reasoning in students for inverse problems. The research method used to reveal reversible reasoning uses qualitative research methods with a case study approach. Sampling was carried out using purposive sampling technique where the research sample was selected based on reversible reasoning criteria. Retrieval research data uses the results of students' mathematical work, think aloud, interviews, and the components that cause reversible reasoning. The results of the study indicate that the process of reversible reasoning begins with obstacles that cause participants to be unable to continue the settlement process resulting in a metacognition process by analyzing the problem again analytically and developing other heuristic strategies. Participants showed a change in perspective where he initially interpreted inverse as the act of swapping independent and dependent variables and switched to interpreting inverse as the opposite of a function process involving analogy and image representation. The contribution of this research provides knowledge that reversible reasoning can occur in understanding and solving mathematical problems in inverse material.
\end{abstract}

Keywords: Analytic; intuitive; inverse problems; metacognition; reversible reasoning.

This is an open access article under the Creative Commons Attribution 4.0 International License 
DOI: https://doi.org/10.24127/ajpm.v10i2.3450

\section{PENDAHULUAN}

Saat ini kajian tentang penalaran reversibel mengalami perkembangan yang signifikan dan merupakan salah satu topik yang menarik beberapa tahun terakhir. Hal ini dikarenakan penalaran reversibel terkait dengan banyaknya masalah dalam matematika, misalkan pada masalah operasional (penjumlahan, pengurangan, perkalian, dan pembagian) yang melibatkan pengetahuan aljabar dan pecahan (Hackenberg, 2013; Hackenberg \& Lee, 2016; Lee \& Hackenberg, 2014). Beberapa hasil penelitian menunjukkan pentingnya penalaran reversibel dalam meminimalkan ketidakmampuan belajar (learning disabilities) dalam praktek pembelajaran baik siswa maupun guru (Stefano, Litster, \& MacDonald, 2017; Dougherty dkk, 2016; Dougherty dkk, 2015), pengembangan strategi pembelajaran (Mackrell, 2011; Nolte \& Pamperien, 2017), penilaian berbasis proses (Sangwin \& Jones, 2017), dan tuntutan kurikulum (Lubin, Simon, Houdé, \& De Neys, 2015). Sehingga bukan merupakan hal yang baru dalam penelitian pendidikan matematika.

\begin{tabular}{|c|c|}
\hline $\begin{array}{l}\text { Istilah } \\
\text { awalnya }\end{array}$ & $\begin{array}{c}\text { penalaran } \\
\text { berdasarkan }\end{array}$ \\
\hline reversibilitas & Piaget dan \\
\hline
\end{tabular}
Piaget (Inhelder \& Piaget, 1958) mengungkapkan bahwa reversibilitas yang merupakan kemampuan mental siswa dalam mengubah arah berpikirnya kembali ke titik awal. Secara operasional ia membedakan reversibilitas dalam dua bentuk, yakni negasi dan reciprocity. Negasi mengungkapkan ide bahwa setiap operasi memiliki kebalikan, misalkan penjumlahan dan pengurangan, sedangkan reciprocity merujuk pada koordinasi antara dua sisi suatu hubungan, misalkan jika $\mathrm{a}>\mathrm{b}$ maka $\mathrm{b}<\mathrm{a}$ atau jika $\mathrm{a}=\mathrm{b}$ maka $\mathrm{b}=\mathrm{a}$.
Sedangkan Krutetskii (Krutetskii, 1976) mengungkapkan reversibilitas sebagai proses mental dalam merekonstruksi arah berpikirnya yang beralih dari berpikir langsung ke arah sebaliknya. Krutetskii berpendapat bahwa jika siswa mempelajari enam tahap $(\mathrm{A}, \mathrm{B}, \mathrm{C}, \mathrm{D}, \mathrm{E}, \mathrm{F})$, maka siswa tersebut telah mempelajari proses dari A ke $\mathrm{F}$. Namun membalikkan proses dari F ke A tidak perlu mengikuti urutannya, tetapi penalaran reversibel hanya membutuhkan proses yang dimulai dari $\mathrm{F}$ dan menyimpulkan A.

Berdasarkan konsep reversibilitas yang diperkenalkan oleh Piaget dan Krutetskii, komunitas riset telah berupaya menguraikan reversibilitas menjadi beberapa bentuk. Ramful (Ramful, 2009, 2014, 2015; Ramful \& Olive, 2008) berpendapat bahwa penalaran reversibel sebagai fleksibilitas mental individu yang mampu mengantisipasi dan melihat kembali masalah secara analitik. Ia menambahkan situasi masalah yang diberikan merupakan pemicu (trigger) yang menyebabkan siswa melakukan penalaran reversibel. Sementara Hackenberg (Hackenberg, 2010; Hackenberg \& Lee, 2015, 2016) mengungkapkan bahwa penalaran reversibel terkait dengan skema antisipasif dimana siswa berupaya mencapai hasil pengalaman sebelumnya dengan menghasilkan penyebab dari suatu masalah. Mampu menghasilkan penyebab dari suatu hasil cenderung membutuhkan refleksi secara analitik sehingga siswa mengalami perubahan perubahan sudut pandang. Dalam artikel ini, kami mendefinisikan penalaran reversibel sebagai proses mental dalam mengubah sudut pandang berdasarkan situasi masalah yang diberikan.

Banyak hasil penelitian terkait penalaran reversibel, akan tetapi 
terbatas pada bagaimana menemukan nilai yang hilang pada masalah penjumlahan dan pengurangan, perkalian atau pembagian, atau kuantitas yang tidak diketahui atau menemukan bentuk lain suatu persamaan dengan mengembangkan konsep aljabar dan pecahan (Hackenberg, 2010; Hackenberg \& Lee, 2015; Ramful, 2009, 2015; Ramful \& Olive, 2008; Lesllie P. Steffe \& Olive, 2009; Tzur, 2004). Berdasarkan penelitian yang sudah pernah dilakukan, terlihat bahwa masih sedikit kajian yang mengungkapkan penyebab terjadinya penalaran reversibel. Selain itu, belum ada juga yang mengaitkan penalaran reversible dari beberapa materi matematika, khususnya pada masalah matematik di tingkat Universitas, misalkan membangun hubungan eksponen dan logaritma, menemukan $\theta$ pada fungsi trigonometri, mensketsa grafik antiturunan berdasarkan turunan yang diketahui, dan hubungan antara fungsi dan invers. Hal tersebut menjadi penting untuk dikembangkan dalam penelitian ini, karena permasalahan di tingkat universitas lebih kompleks dibandingkan di tingkat dasar.

Dalam artikel ini, difokuskan pada masalah invers. Berdasarkan hipotesis awal, terdapat dugaan bahwa penyebab mahasiswa menyelesaikan masalah dengan penalaran reversibel untuk masalah invers, yakni: ketika mereka mengalami hambatan atau tidak mampu melanjutkan proses pemecahan masalah, siswa berusaha menemukan alternatif lainnya (membangun kembali konsep prasyarat dan pengalaman sebelumnya). Hal ini menjadi pengembangan dari temuan Ramful (Ramful, 2009, 2014, 2015) bahwa penalaran reversibel terjadi berdasarkan situasi masalah. Sehingga perlu ditelusuri secara mendalam melalui studi kasus dengan menganalisis hasil kerja, think aloud, wawancara, dan mengungkapkan komponen-komponen yang menyebabkan terjadinya penalaran reversible.

\section{METODE PENELITIAN}

Dalam penelitian ini, metode penelitian yang digunakan adalah metode kualitatif dengan pendekatan studi kasus. Alasan pemilihan metode ini adalah untuk memahami, mengenali fenomena dan mengungkap hal-hal yang unik dari perilaku mahasiswa dalam menyelesaikan masalah.

Penelitian ini dilakukan di Universitas Cokroaminoto Palopo, dimana pengambilan sampel dilakukan dengan menggunakan teknik purposive sampling di mana sampel penelitian dipilih berdasarkan kriteria penalaran reversibel. Pengambilan data dalam penelitian ini menggunakan hasil karya matematika mahasiswa, berpikir keras, wawancara, dan komponen yang menyebabkan penalaran reversibel. Analisis diperoleh dari serangkaian wawancara dengan satu mahasiswa, Adjie (Ad). Ia dipilih dari 34 mahasiswa yang terdaftar dalam kelas yang sama dan berusia 19 tahun. Alasan pemilihannya adalah (1) selama pemberian instrumen awal, ia mengalami hambatan dan tidak mampu meneruskan proses berdasarkan dugaan awalnya, namun berusaha menemukan solusinya; (2) ia mampu mengkonstruk kembali pengetahuan sebelumnya dan digunakan untuk menyelesaikan masalah yang diberikan; dan (3) ia mampu mengkomunikasikan ide yang muncul dalam pikirannya. Berdasarkan analisa awal, kami menduga bahwa konsepsi Ad dapat memberikan wawasan tentang proses terjadinya penalaran reversibel. 
DOI: https://doi.org/10.24127/ajpm.v10i2.3450

\section{Pengembangan Tes}

Untuk memperoleh gambaran proses terjadinya penalaran reversibel peserta, Ad diminta untuk mengerjakan kembali tugas yang telah dikembangkan dengan memodifikasi instrumen dari penelitian sebelumnya (Tabel 1). Instrumen Paoletti (Paoletti, 2015; Paoletti, Stevens, Hobson, Moore, \& LaForest, 2018) digunakan untuk tugas 1 dengan menggunakan fungsi polinomial. Tugas tersebut berbeda dengan tugas yang digunakan selama penyelidikan awal, karena yang diinginkan dari peserta yaitu keluar dari situasi yang sering mereka hadapi dan memunculkan penalaran reversibel secara alami. Sehinga disajikan masalah dengan situasi baru yang memungkinkan mereka membalikkan pemikiran dari situasi masalah yang berbeda dari biasanya, mengembangkan pemikirannya pada masalah dengan situasi yang baru, dan mengubah sudut pandangnya.

Tabel 1. Pengembangan tugas

\begin{tabular}{lll}
\hline \multicolumn{1}{c}{ Tugas } & $\begin{array}{c}\text { Karakteristik } \\
\text { Tugas }\end{array}$ & $\begin{array}{l}\text { Solusi yang } \\
\text { Mungkin }\end{array}$ \\
\hline Tugas \#1: & Mahasiswa & Tugas \\
Jika & perlu & tersebut \\
$f(x)=$ & memahami & menanyakan \\
$\frac{x^{2}+2 x+6}{x^{2}+x-5}$ dan & hubungan & nilai $x$ dari \\
$f^{-1}(2)=$ & antara & $f^{-1}(2)=x$ \\
$x$. Jelaskan & $f(x)=y$ & setara \\
bagaimana & setara & dengan \\
anda & $f^{-1}(y)=x$ & $f(x)=2$. \\
menentukan & & \\
nilai $x$ ? & & \\
\hline
\end{tabular}

\section{Prosedur Pengumpulan Data}

Wawancara berbasis tugas digunakan untuk mengumpulkan data tentang proses terjadinya penalaran reversibel (Goldin, 2000). Diberikan penekanan kepada subjek untuk tidak peduli dengan jawabannya apakah benar atau salah dan subjek diminta untuk melakukan "think aloud" selama menyelesaikan tugas (Creswell, 2012; Miles, Huberman, \& Saldana, 2014). Wawancara dilakukan selama 30-60 menit dan dilakukan setiap akhir pekan. Ad diminta untuk menjawab semua tugas dan menjawab pertanyaan tambahan yang diajukan mengenai alasan, strategi yang digunakan dan halhal yang membantu mereka selama menyelesaikan tugas. Selama wawancara, mereka bebas mengungkapkan tanggapan terkait tugas yang diberikan. Wawancara tersebut direkam dengan menggunakan audio dan video untuk analisis lebih lanjut.

\section{Analisis Data}

Sebelum melakukan analisis, diberikan gambaran umum tentang pengembangan kerangka analitik yang digunakan untuk mengkodekan dan menganalisis sumber data. Pengkodean yang dikembangkan menggunakan data pemikiran mahasiswa. Analisis data dilakukan setelah seluruh sesi wawancara dilakukan dan menggunakan pengkodean awal (initial coding) dari rekaman wawancara. Kemudian mendengarkan rekaman wawancara, hasil kerja, dan mentranskrip sesuai kebutuhan. Fokus dari pengkodean ini adalah apa yang menyebabkan mereka mengubah sudut pandang dari situasi masalah yang diberikan. Semua data wawancara dikumpulkan, rekaman audio dan video ditranskrip, dan salinan hasil kerja mahasiswa digabungkan dengan setiap transkrip. Semua bentuk data dianalisis secara sistematis dan secara independen dikodekan sesuai dengan karakteristik panalaran reversibel yang dilakukan mahasiswa. Untuk tugas mahasiswa dianalisis dengan menentukan apakah Ad berhasil menyelesaikan setiap tugas, mengidentifikasi penyebab mereka 
mengubah sudut pandangnya, dan strategi yang digunakan dalam mengubah sudut pandang tersebut.

Untuk analisis data, digunakan metode analisis tematik yang dikembangkan Braun \& Clarke (Braun \& Clarke, 2006), tujuannya adalah mengidentifikasi pola dari tema melalui serangkaian data yang ada untuk menjawab pertanyaan penelitian yang diajukan. Pola dari tema diidentifikasi melalui proses yang sangat teliti dari pengenalan data (data familiarization), pengkodean data, dan pengembangan tema dan revisi. Metode ini disusun dalam enam tahap (Braun \& Clarke, 2006).

Enam tahap metode yang digunakan dalam penelitian yaitu, Pertama, membaca transkrip wawancara secara berulang-ulang. Kedua, mengembangkan kode awal dengan mencari kata atau frasa yang menunjukkan bahwa partisipan mengubah sudut pandangnya dari situasi masalah yang diberikan. Ketiga, menentukan tema dengan membuat, menetapkan, memodifikasi kode untuk memahami hubungan-hubungannya dan mengembangkan tema potensial. Berdasarkan kode awal, kutipan-kutipan yang terkait dibandingkan untuk mencari tema diantara kode-kode. Keempat, meninjau kembali tema dengan mengidentifikasi tema-tema pada tahap sebelumnya, membahas kesesuaiannya dengan data, mendiskusikan tema. Beberapa tema mengalami perubahan pada penamaan atau deskripsi, selain itu menghapus tema yang tidak memiliki bukti yang untuk membuktikan bahwa partisipan melakukan penalaran reversibel. Kelima, mendefinisikan dan menamakan tema-tema. Mendefinisikan tema dengan memasukan ide utama dan membuat uraian tentang masing-masing tema (Dapat dilihat pada Tabel 2). Bagian ini sangat penting untuk menjawab pertanyaan penelitian. dan Keenam, menghasilkan laporan.

Tabel 2. Pengembangan tema penalaran reversibel

\begin{tabular}{|c|c|c|}
\hline Tema & Deskripsi & $\begin{array}{l}\text { Frasa yang } \\
\text { digunakan }\end{array}$ \\
\hline Intuitif & $\begin{array}{l}\text { secara intuitif } \\
\text { dalam } \\
\text { menyimpulkan } \\
\text { masalah yang } \\
\text { dihadapi } \\
\text { berdasarkan } \\
\text { pengetahuan yang } \\
\text { dimiliki atau } \\
\text { pengalaman } \\
\text { sebelumnya }\end{array}$ & $\begin{array}{l}\text { "masalah ini } \\
\text { menggunaka } \\
\text { n konsep ini" }\end{array}$ \\
\hline Analitik & $\begin{array}{l}\text { - Eksplorasi } \\
\text { mereduksi } \\
\text { kompleksitas } \\
\text { masalah dan hasil } \\
\text { reduksi digunakan } \\
\text { untuk menarik } \\
\text { kesimpulan }\end{array}$ & $\begin{array}{l}\text { "saya coba } \\
\text { mengubah } \\
\text { masalahnya } \\
\text { seperti ini" }\end{array}$ \\
\hline & 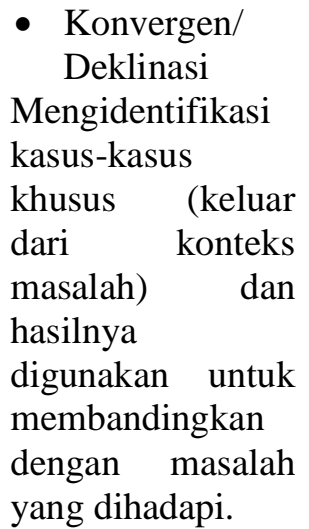 & $\begin{array}{l}\text { "misalkan } \\
\text { saya } \\
\text { mengambil } \\
\text { contoh lain" }\end{array}$ \\
\hline Refraksi & $\begin{array}{l}\text { perubahan sudut } \\
\text { pandang yang } \\
\text { terjadi karena } \\
\text { adanya hambatan, } \\
\text { tidak mampu } \\
\text { melanjutkan } \\
\text { proses pemecahan } \\
\text { masalah, dan } \\
\text { adanya pemikiran } \\
\text { metakognitif } \\
\text { untuk } \\
\text { mengembangkan } \\
\text { strategi heuristik }\end{array}$ & $\begin{array}{l}\text { "sepertinya } \\
\text { ada yang } \\
\text { salah" }\end{array}$ \\
\hline
\end{tabular}


DOI: https://doi.org/10.24127/ajpm.v10i2.3450

\section{HASIL DAN PEMBAHASAN}

Untuk menjawab pertanyaan penelitian, pertama dibahas tanggapan Ad terhadap tugas 1. Berdasarkan tanggapan tersebut, dikembangkanlah model penalaran reversibel Ad dengan menyelidiki pemecahan masalah yang dikembangkan Yimer \& Ellerton (Yimer \& Ellerton, 2010), yakni bagaimana ia menganalisa masalah, merumuskan hasil analisa untuk eksplorasi lebih lanjut, implementasi, melakukan evaluasi, dan refleksi. Fokus kami adalah apakah Ad memiliki skema antisipasi dalam menyajikan kembali pengalaman sebelumnya melalui refleksi, apa yang menyebabkan ia melakukan refleksi dan pada akhirnya terjadi perubahan sudut pandang. Hal tersebut dapat menjawab pertanyaan penelitian: bagaimana proses terjadinya penalaran reversibel.

\section{Solusi Ad untuk masalah invers}

Tabel 3 menunjukkan kutipan dari Ad tentang masalah invers, terkait dengan perilaku dan fase pemecahan masalah dan Gambar 1 menunjukkan hasil penyelesaiannya. Ad memulai dengan membaca masalah (1) dan menyajikan kembali masalah (2), sehingga membangun pemahaman tentang masalah tersebut. Ia mengungkapkan bahwa ia pernah menemukan masalah seperti ini sebelumnya (3) dan menggarisbawahi ide utama pada masalah (4). Hasil pengalaman sebelumnya digunakan untuk menyelidiki masalah (5) yakni menemukan invers dengan mengganti $\mathrm{f}(\mathrm{x})$ sama dengan y. Setelah melakukan analisa masalah, ia mengimplementasikan melalui operasi prosedural dengan melakukan perkalian dan mengelompokkan variabel yang sejenis dengan variabel $x^{2}$ dan $x$ disisi sebelah kiri tanda sama dengan, sedangkan variabel konstant disebelah kanannya (6-7). Ia mencoba menghilangkan variabel $x$ nya, namun ia mengalami kendala (8). Hal tersebut menyebabkan ia kembali memerika langkah-langkah penyelesaian yang dilakukan (9). Selanjutnya ia membuat dugaan bahwa dengan memindahkan variabel konstan ke sebelah kiri tanda sama dengan, maka masalah tersebut dalam bentuk persamaan kuadrat dan dapat dicari dengan memfaktorkan (10-12). Ia berusaha melakukan memfaktorkan tetapi hal tersebut tidak berhasil karena bentuk persamaan kuadrat yang diperoleh terlalu kompleks, sehingga ia mengalami hambatan untuk melanjutkan proses penyelesaian (13). Ia merefleksi kembali tujuan awal dengan menggunakan strategi mengganti $f(x)$ dengan $y$ yang didasarkan pada pengalaman sebelumnya (14).

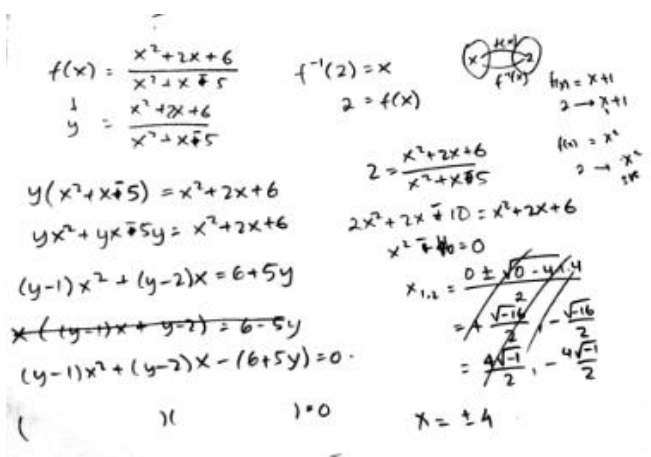

Gambar 1. Hasil kerja Ad

Ia merasa tertantang untuk menyelesaikan masalah tersebut dengan membaca kembali masalah (15), mengingat kembali masalah yang pernah diselesaikan sebelumnya (16) dan menyimpulkan tingkat kesulitan masalah yang dihadapi dibandingkan dengan masalah sebelumnya (17). Ia menggarisbawahi dan menyoroti inversnya sebagai ide utama dan mencoba mencari hubungan antara fungsi dan invers dengan 
mengidentifikasi kasus-kasus khusus di luar dari masalah, misalkan untuk $f(x)=x+1$ dan $f(x)=x^{2}(18-20)$. Frasa yang digunakan dalam mengidentifikasi kasus tersebut adalah "kalau $f^{-1}(2)$ dari $\mathrm{f}$ ini [menunjuk $f(x)=x+1$ ], maka $\mathrm{x}$ sama dengan 1 ", "kalau $f(1)$ berarti hasilnya 2", begitupun dengan kasus lainnya (untuk $f(x)=x^{2}$ ), dilakukan secara berulangulang. Hasil dari identifikasi kasus tersebut ditemukan dugaan awal bahwa "berapa $x$ yang menghasilkan 2" (21). Ia mencoba membuktikan dugaan tersebut dengan dibandingkan terhadapmasalah yang dihadapi, menjustifikasi dengan memvisualisasikannya ke dalam diagram Venn (22-23) dan pada akhirnya menemukan hubungan antara fungsi dan invers yang digunakan untuk menemukan solusi melalui operasi prosedural $(25-28)$.

Ketika ia mencoba menjustifikasi solusi ia tidak yakin dengan solusi yang didapatkan, sehingga ia melakukan refleksi dengan mensubstitusi nilai $x$ dan keduanya menghasilkan 2 (29-30). Ia menunjukkan kegembiraan tentang betapa sulitnya masalah itu dan tidak menduga proses pemecahan masalah yang dilakukan seperti itu (31). Ia merefleksi cara yang dilakukan sebelumnya mungkin menghasilkan solusi yang sama, namun ia tidak mampu meneruskan proses penyelesaiannya.

Tabel 3. Kutipan dan pengkodean dari solusi Ad untuk masalah invers

\begin{tabular}{|c|c|c|c|}
\hline & Kutipan & Perilaku & Fase \\
\hline (1) & Membaca ulang masalah dengan keras & Membaca masalah & Menganalisa \\
\hline (2) & $\begin{array}{l}\text { Diminta untuk menemukan nilai } x \text { dari } \\
f^{-1}(2)\end{array}$ & $\begin{array}{l}\text { Mengemukakan kembali } \\
\text { masalah }\end{array}$ & masalah \\
\hline (3) & $\begin{array}{l}\text { Saya pernah menyelesaikan masalah ini } \\
\text { sebelumnya }\end{array}$ & Menilai kesamaan masalah & \\
\hline (4) & Inikan invers [menggarisbawahi] & $\begin{array}{l}\text { Mengidentifikasi ide utama } \\
\text { pada masalah }\end{array}$ & \\
\hline (5) & $\begin{array}{l}\text { Saya pikir harus mencari inversnya dulu, } \\
\text { misalkan } f(x) \text { diganti } y\end{array}$ & Menyelidiki masalah & \\
\hline (6) & $\begin{array}{l}\text { Jadi } y \text { sama dengan } \frac{x^{2}+2 x+6}{x^{2}+x-5} \text {, ini bisa } \\
\text { dikalikan }\end{array}$ & $\begin{array}{l}\text { Melakukan operasi } \\
\text { prosedural }\end{array}$ & Implementasi \\
\hline (7) & $\begin{array}{l}\text { Saya mengelompokkan variabel yang } \\
\text { sejenis }\end{array}$ & & \\
\hline (8) & Dibagi dengan $x$ & & \\
\hline (9) & Tunggu, sepertinya saya lupa & $\begin{array}{l}\text { Memeriksa langkah-langkah } \\
\text { yang ia lakukan }\end{array}$ & \\
\hline (10) & Oh yah, ini bisa difaktorkan kayaknya & Membuat dugaan & \\
\hline (11) & $\begin{array}{l}\text { Hmmm...[diam selama } 15 \text { detik }] \\
\text { Bagaimana yah? } \\
{\left[\text { menuliskan }(y-1) x^{2}+(y-2) x=6+5 y\right]}\end{array}$ & Mengalami hambatan & \\
\hline (12) & $\begin{array}{l}\text { Oh.. berarti ini menjadi satu dan bisa } \\
\text { difaktorkan }\end{array}$ & Mengidentifikasi ide baru & \\
\hline (13) & $\begin{array}{l}\text { Sebentar... [diam } 15 \text { detik] gimana yah, } \\
\text { sepertinya saya terhenti disini, ini } \\
\text { sebenarnya tidak difaktorkan }\end{array}$ & $\begin{array}{l}\text { Mengalami hambatan untuk } \\
\text { melanjutkan proses }\end{array}$ & Evaluasi \\
\hline (14) & $\begin{array}{l}\text { Rencananya saya mau jadikan } x \text { nya } \\
\text { menjadi satu di salah satu sisi dan tinggal } \\
\text { diganti dengan } f^{-1} \text { nya }\end{array}$ & Melakukan refleksi & \\
\hline
\end{tabular}


DOI: https://doi.org/10.24127/ajpm.v10i2.3450

\begin{tabular}{|c|c|c|c|}
\hline & Kutipan & Perilaku & Fase \\
\hline$(15)$ & $\begin{array}{l}\text { Disini diketahui } f(x) \text { nya dan tentukan } x \\
\text { dari } f^{-1}(2)\end{array}$ & Membaca kembali masalah & $\begin{array}{l}\text { Menganalisa } \\
\text { masalah }\end{array}$ \\
\hline (16) & $\begin{array}{l}\text { Kalau soal sebelumnya } f(x) \text { tidak seperti } \\
\text { ini, dan biasanya saya kerja dengan cara } \\
\text { seperti ini }\end{array}$ & $\begin{array}{l}\text { Mengingat kembali } \\
\text { kesamaan masalah }\end{array}$ & \\
\hline (17) & Sepertinya ini lebih sulit dari sebelumnya & Menilai kesulitan masalah & \\
\hline (18) & $\begin{array}{l}\text { Tunggu sebentar } \cdots \text { saya lihat kayaknya } \\
f^{-1} \text { bisa saya buat hubungan }\end{array}$ & $\begin{array}{l}\text { Menyelidiki kembali ide } \\
\text { utama }\end{array}$ & \\
\hline (19) & $\begin{array}{l}\text { Kalau misalkan } f(x) \text { sama dengan } x+1, \\
f^{-1}(2) \text { adalah berapa nilai } x \text { yang } \\
\text { menghasilkan } 2 \text {, berari } x \text { sama dengan } 1\end{array}$ & $\begin{array}{l}\text { Mengidentifikasi kasus-kasus } \\
\text { khusus (keluar dari konteks } \\
\text { masalah) }\end{array}$ & Implementasi \\
\hline$(20)$ & $\begin{array}{l}\text { Saya coba kalau } f(x) \text { sama dengan } x^{2}, x \\
\text { nya dalam bentuk akar }\end{array}$ & & \\
\hline (21) & Artinya $x$ yang hasilnya 2 & $\begin{array}{l}\text { Menyimpulkan dugaan awal } \\
\text { berdasarkan identifikasi } \\
\text { kasus-kasus khusus }\end{array}$ & \\
\hline$(22)$ & $\begin{array}{l}\text { Oh sebentar, kalau misalnya } f^{-1}(2) \text { sama } \\
\text { dengan } x \text {. artinya } 2 \text { sama dengan } f(x)\end{array}$ & $\begin{array}{l}\text { Membandingkan dugaan } \\
\text { awal dengan masalah yang } \\
\text { dihadapi }\end{array}$ & \\
\hline (23) & $\begin{array}{l}\text { Invers dari } 2 \text { itu kan } x \text {, kalau misalnya } \\
\text { digambar } x \text { disini [sebagai domain] dan } \\
2 \text { disini [sebagai range]. Ini } f(x) \text { dan ini } \\
\text { inversnya. Berarti untuk menemukan } x \\
\text { dengan cara ini. }\end{array}$ & Menjustifikasi ide baru & \\
\hline (24) & Ohh..ternyata seperti ini & Menilai kesulitan & \\
\hline (25) & Jadi 2 sama dengan $f(x)$ & $\begin{array}{l}\text { Menemukan strategi untuk } \\
\text { menyelesaikan masalah }\end{array}$ & \\
\hline (26) & Ini 2 sama dengan $\frac{x^{2}+2 x+6}{x^{2}+x-5}$, berarti & $\begin{array}{l}\text { Melakukan operasi } \\
\text { prosedural }\end{array}$ & \\
\hline (27) & $\begin{array}{l}2 x^{2}+2 x-10=x^{2}+2 x+6 \\
\text { Sisi yang sebelah kanan dipindahkan ke } \\
\text { kiri, jadi } x^{2}-16=0\end{array}$ & & \\
\hline (28) & Jadi $x$ adalah 4 dan -4 & Menemukan solusi & \\
\hline (29) & $\begin{array}{l}\text { Tunggu, apa bisa nilai } x \text { ada } 2 \text {. Saya pikir } \\
\text { ini benar }\end{array}$ & Menjustifikasi solusi & Evaluasi \\
\hline (30) & $\begin{array}{l}\text { Kalau saya ganti } x \text { dengan } 4 \text { dan }-4 \\
\text { disini, hasilnya adalah } 2 \text {. Sesuai }\end{array}$ & & \\
\hline (31) & $\begin{array}{l}\text { Ini menantang, saya tidak menduga bisa } \\
\text { berpikir sejauh ini }\end{array}$ & Menilai kesulitan & Refleksi \\
\hline$(32)$ & $\begin{array}{l}\text { Mungkin dengan cara sebelumnya bisa } \\
\text { digunakan, tapi ini lebih mudah }\end{array}$ & Merefleksi proses & \\
\hline
\end{tabular}

Pertanyaan penelitian dalam artikel ini adalah bagaimana proses terjadinya penalaran reversible? Dari hasil analisa ditemukan faktor penyebab Ad melakukan penalaran reversibel pada masalah invers; pertama. analisa masalah secara intuitif mengakibatkan Ad mengalami hambatan dan tidak mampu melanjutkan proses penyelesaian; kedua, adanya peranan metakognitif untuk membangun hubungan sebab-akibat dengan menganalisa kembali masalah dan mengembangkan strategi heuristik lainnya. Analisa masalah secara intuitif terlihat ketika Ad membandingkan 
DOI: https://doi.org/10.24127/ajpm.v10i2.3450

masalah yang dihadapi dengan pengalaman sebelumnya dalam menyelesaikan masalah invers dengan menggunakan strategi umum, yakni menukar variabel independen (x) dan dependen (y) dari fungsi asli dan penyelesaian untuk variabel dependen didefinisikan sebagai fungsi asli. Hal ini merupakan salah satu dekomposisi genetik dari temuan Paoletti dkk (Paoletti et al., 2018) tentang makna invers sebagai tindakan menukar $\mathrm{x}$ dan $\mathrm{y}$ dan penyelesaiannya untuk $\mathrm{y}$. Berdasarkan teori skema antisipasi (Ron Tzur, 2011; Simon, Kara, et al., 2016; Simon, Placa, et al., 2016; Tzur, 2007; Tzur \& Simon, 2004), analisis masalah secara intuitif mengakibatkan Ad berusaha mencapai pengalaman sebelumnya didasarkan pada kesamaan (familiaritas) sehingga tidak membangun makna invers sebagai kebalikan dari proses fungsi.

Dalam teori dual-proses yang dikembangkan Leron (Leron \& Hazzan, 2009; Leron \& Paz, 2014), analisa masalah yang dominan pada intuitif menyebabkan terjadinya kesalahan, hambatan, dan miskonsepsi ketika siswa memecahkan masalah. Hal tersebut terjadi pada Ad melalui strategi menukar variabel independen dan dependen yang didasarkan pengalaman sebelumnya, ia mengalami hambatan dan tidak mampu meneruskan proses penyelesaian. Ia tidak memiliki skema antisipasi dalam menguraikan penyelesaian pada $\mathrm{x}$ dalam $\mathrm{y}$ untuk menemukan akar persamaan polinomial. Karena mengalami hambatan, ada upaya untuk melakukan refleksi dengan mengecek kembali langkah-langkah penyelesaian dan strategi yang digunakan. Hal inilah yang membedakan dengan subjek lainnya, karena terkadang didapatkan mahasiswa yang mengalami kendala dan tidak ada usaha untuk menemukan alternatif lainnya.

Ad merefleksikan kembali permasalahan dengan melihat urutan aktivitas selama memecahkan masalah, membandingkan kesamaan permasalahan berdasarkan pengalaman sebelumnya, dan menilai tingkat kesulitan. Hal ini sesuai dengan pendapat Sriraman (Sriraman, 2015) bahwa aktivitas mental dalam melakukan refleksi diantaranya menduga dan memeriksa contoh dan non-contoh yang sifatnya plausible, mengaitkan dengan pengalaman sebelumnya, pengambilan keputusan selama dan setelah eksekusi dan verifikasi, memikirkan kesamaan dalam masalah, dan mengabstrakkan kesamaan struktural pada masalah. Sedangkan menurut Tzur (Ron Tzur, 2011; Tzur, 2007) mengungkapkan refleksi pada hubungan aktivitas-efek (activity-effect relationship) merupakan asimilasi dari situasi masalah ke dalam konsepsi, dimana asimilasi menetapkan tujuan (menghasilkan nilai $x$ dari $f^{-1}(x)$ ) dan memanggil urutan aktivitas (Strategi menukar variabel independen dan dependen) untuk mencapai tujuan tersebut.

Adanya kesadaran untuk melakukan refleksi dengan menganalisa kembali masalah secara analitik dan mendetaksi kognisi yang salah merupakan salah satu aspek dalam pemikiran metakognisi (Kim, Park, Moore, \& Varma, 2013; Yimer \& Ellerton, 2010). Hal tersebut dapat memunculkan konsepsi baru untuk membangun hubungan sebab akibat dari masalah fungsi dan invers. Salah satu strategi heuristik yang dilakukan Ad adalah mereduksi kompleksitas masalah yang ditandai dengan menyoroti makna invers dan mengidentifikasi kasus-kasus khusus diluar dari konteks masalah 
$\left(f(x)=x+1\right.$ dan $\left.\quad f(x)=x^{2}\right), \quad$ dan menganalogikan kasus tersebut dengan mengungkapkan"kalau $f^{-1}(2)$ dari $\mathrm{f}$ ini [menunjuk $f(x)=x+1$ ], maka $\mathrm{x}$ sama dengan 1" secara berulang-ulang. Berdasarkan analogi, ia menemukan bahwa masalah identik dengan menemukan "berapa $x$ yang menghasilkan 2" dan dibuktikan dengan memvisualisasikan masalah ke dalam diagram venn. Hal ini sejalan dengan pendapat Haciomerouglu (Haciomeroglu, 2007; Haciomeroglu et al., 2009, 2010), Flanders (Flanders, 2014), dan Lubin dkk (Lubin et al., 2015) bahwa memaknai masalah secara verbal dan memvisualisasikan masalah terkadang diperlukan untuk menemukan situasi masalah.

Hasil identifikasi kasus tersebut digunakan untuk membandingkan dengan masalah yang dihadapi (menemukan $x$ dari $f^{-1}(2)$ ) dan menemukan penyelesaian dari masalah tersebut. Dalam hal ini Ad memaknai invers sebagai kebalikan dari proses fungsi, yang merupakan salah satu dekomposisi genetik yang dikembangkan Paoletti dkk (Paoletti et al., 2018). Karena Krutetskii (Krutetskii, 1976) memaknai penalaran reversibel sebagai merekonstruksi arah berpikir, kami menyimpulkan bahwa Ad mengalami perubahan sudut pandang dari tindakan menukar variabel independen dan dependen beralih ke tindakan memaknai invers sebagai kebalikan dari proses fungsi. Adanya hambatan disebabkan analisa masalah secara intuitif dan pemikiran metakognitif merupakan penyebab Ad melakukan penalaran reversibel. Hal tersebut mungkin terjadi untuk mahasiswa lainnya.

Berdasarkan teori skema antisipasif yang dikembangkan Steffe \& Olive (Lesllie P. Steffe \& Olive, 2009),
Hackenberg (Hackenberg, 2010) dan Simon \& Tzur (Ron Tzur, 2011; Simon, Kara, et al., 2016; Simon, Placa, et al., 2016; Tzur, 2007; Tzur \& Simon, 2004), kami menemukan bahwa sebelum menggunakan hasil skema (fungsi invers) untuk menghasilkan penyebab (invers sebagai kebalikan proses fungsi), siswa melakukan berbagai aktivitas mental melalui refleksi dengan menyajikan kembali pengalaman sebelumnya dan mengembangkan strategi heuristik. Menghasilkan makna invers sebagai kebalikan proses fungsi merupakan upaya Ad membangun hubungan sebabakibat ke dalam pengalaman baru (mengidentifikasi kasus di luar masalah), dan memisahkan penyebab agar memperoleh hasil dengan menyusun kembali masalah (membandingkan hasil identifikasi di luar masalah). Selain itu, jika ditinjau dari teori dual-proses (Sistem 1 dan Sistem 2) (Leron \& Hazzan, 2009; Leron \& Paz, 2014), apa yang ditunjukkan Ad merupakan kemajuan berpikir dengan memberikan peran analitik sebagai monitor dan kritik untuk mengoreksi atau mengganti analisa secara intuitif (perubahan dari Sistem 1 ke Sistem 2).

\section{KESIMPULAN DAN SARAN}

Penelitian ini mengungkapkan proses terjadinya penalaran reversibel subjek Ad. Dari hasil pengembangan penelitian sebelumnya, ditemukan bahwa penalaran reversibel tidak hanya sensitif pada sifat numerik dari parameter masalah, tetapi dapat dikonstruk berdasarkan hubungan sebab-akibat (Ramful, 2009, 2014, 2015), dan perlu ada pemicu untuk menemukan jalur alternatif dalam membalikkan situasi masalah (Flanders, 2014; Haciomeroglu et al., 2009, 2010). 
Selain itu kami sependapat bahwa skema antisipasi merupakan prasayarat terjadinya penalaran reversibel (Hackenberg, 2010; Ron Tzur, 2011; Simon, Kara, et al., 2016; Simon, Placa, et al., 2016; Tzur \& Simon, 2004). Terakhir, Penalaran reversibel yang ditunjukkan Ad merupakan salah satu tipe yang ditemukan dalam penelitian ini. Tipe ini disebut dengan istilah "refraksi" yakni perubahan sudut pandang yang terjadi karena adanya hambatan, tidak mampu melanjutkan proses pemecahan masalah, dan adanya pemikiran metakognitif untuk mengembangkan strategi heuristik.

Ada beberapa hal penting sebagai saran untuk penelitian selanjutnya, yakni (1) diduga masih ada beberapa tipe penalaran reversibel khususnya untuk mahasiswa yang tidak secara langsung mengalami hambatan, sehingga ada kemungkinan mereka melakukan penalaran reversibel dalam menyelesaikan masalah; (2) Fokus penelitian ini yakni pada masalah invers. Sehingga untuk peneliti selanjutnya dapat menyelidiki untuk konsep-konsep lain, misalkan pada kalkulus, yakni, menemukan fungsi asli berdasarkan turunan fungsi yang diketahui atau mensketsa grafik fungsi berdasarkan grafik fungsi turunan. membangun hubungan antara proses diffrensiasi dan integrasi.

\section{DAFTAR PUSTAKA}

Braun, V., \& Clarke, V. (2006). Using thematic analysis in psychology: qualitative reaserch in psychology (Vol. 3). University of the West of England. https://doi.org/10.1191/14780887 06qp063oa

Chun, J. (2017). Construction of the Sum of Two Covarying Oriented Quantities. Potential Analysis.
University of Georgia. https://doi.org/10.1007/s11118013-9365-6

Creswell, J. W. (2012). Educational research: Planning, conducting, and evaluating quantitative and qualitative research. Educational Research (Vol. 4). https://doi.org/10.1017/CBO9781 107415324.004

Di Stefano, M., Litster, K., \& MacDonald, B. L. (2017). Mathematics Intervention Supporting Allen, a Latino EL: A Case Study. Education Sciences, 7(2), 57. https://doi.org/10.3390/educsci70 20057

Dougherty, B., Bryant, D. P., Bryant, B. R., \& Shin, M. (2016). Helping Students With Mathematics Difficulties Understand Ratios and Proportions. TEACHING Exceptional Children, 49(2), 96105.

https://doi.org/10.1177/00400599 16674897

Dougherty, B. J., Bryant, D. P., Bryant, B. R., Darrough, R. L., \& Pfannenstiel, K. H. (2015). Developing Concepts and Generalizations to Build Algebraic Thinking: The Reversibility, Flexibility, and Generalization Approach. Intervention in School and Clinic, 50(5), 273-281. https://doi.org/10.1177/10534512 14560892

Flanders, S. T. (2014). Investigating Flexibility, Reversibility, and Multiple Representation in a Calculus Enviroment. University of Pittsburg.

Goldin, G. A. (2000). A Scientific Perspective on Structured, TaskBased Interviews in Mathematics 
DOI: https://doi.org/10.24127/ajpm.v10i2.3450

Education Research. Handbook of Research Design in Mathematics and Science Education. https://doi.org/10.4324/97814106 02725.ch19

Haciomeroglu, E. S. (2007). Calculus Student's Understanding of Derivative Graphs: Problem of Representation in Calculus. The Florida State University.

Hackenberg, A. J. (2010). Students' reasoning with reversible multiplicative relationships. Cognition and Instruction, 28(4), 383-432.

https://doi.org/10.1080/07370008. 2010.511565

Hackenberg, A. J. (2013). The fractional knowledge and algebraic reasoning of students with the first multiplicative concept. Journal of Mathematical Behavior, 32(3), 538-563. https://doi.org/10.1016/j.jmathb.2 013.06.007

Hackenberg, A. J., \& Lee, M. Y. (2015). Relationships between students' fractional knowledge and equation writing. Journal for Research in Mathematics Education, 46(2), 196-243. https://doi.org/10.5951/jresemathe duc.46.2.0196

Hackenberg, A. J., \& Lee, M. Y. (2016). Students' distributive reasoning with fractions and unknowns. Educational Studies in Mathematics, 93(2), 245-263. https://doi.org/10.1007/s10649016-9704-9

Inhelder, \& Piaget. (1958). The Growth of Logical Thinking From Child to Adolecence. New York: Basic Books, Inc.

Kim, Y. R., Park, M. S., Moore, T. J., \& Varma, S. (2013). Multiple levels of metacognition and their elicitation through complex problem-solving tasks. Journal of Mathematical Behavior, 32(3), 377-396.

https://doi.org/10.1016/j.jmathb.2 013.04 .002

Krutetskii, V. A. (1976). The Psychology of Mathematical Abilities in Schoolchildren. Journal for Research in Mathematics Education (Vol. 8). https://doi.org/10.2307/748528

Lee, M. Y., \& Hackenberg, A. J. (2014). Relationships Between Fractional Knowledge and Algebraic Reasoning: the Case of Willa. International Journal of Science and Mathematics Education, 12(4), 975-1000. https://doi.org/10.1007/s10763013-9442-8

Leron, U., \& Hazzan, O. (2009). Intuitive vs analytical thinking: Four perspectives. Educational Studies in Mathematics, 71(3), 263-278.

https://doi.org/10.1007/s10649008-9175-8

Leron, U., \& Paz, T. (2014). Functions via everyday actions: Support or obstacle? Journal of Mathematical Behavior, 36, 126134. https://doi.org/10.1016/j.jmathb.2 014.09.005

Lubin, A., Simon, G., Houdé, O., \& De Neys, W. (2015). Inhibition, conflict detection, and number conservation. ZDM - Mathematics Education, 47(5), 793-800. https://doi.org/10.1007/s11858014-0649-0

Mackrell, K. (2011). Design decisions in interactive geometry software. ZDM - International Journal on Mathematics Education, 43(3), 373-387. 
DOI: https://doi.org/10.24127/ajpm.v10i2.3450

https://doi.org/10.1007/s11858011-0327-4

Miles, M. B., Huberman, A. M., \& Saldana, J. (2014). Qualitative Data Analysis: A Methods Sourcebook (Third Edit). United States of America: SAGE Publications, Inc.

Nathan, M. J., \& Koedinger, K. R. (2000). Teachers' and researchers' beliefs about the development of algebraic reasoning. Journal for Research in Mathematics Education, 31(2), 168-190.

https://doi.org/10.2307/749750

Nolte, M., \& Pamperien, K. (2017). Challenging problems in a regular classroom setting and in a special foster programme. ZDM Mathematics Education, 49(1), 121-136.

https://doi.org/10.1007/s11858016-0825-5

Paoletti, T. (2015). Pre-Service Teachers' Development of Bidirectional Reasoning.

Paoletti, T., Stevens, I. E., Hobson, N. L. F., Moore, K. C., \& LaForest, K. R. (2018). Inverse function: Pre-service teachers' techniques and meanings. Educational Studies in Mathematics, 97(1), 93-109.

https://doi.org/10.1007/s10649017-9787-y

Ramful, A. (2009). Reversible Reasoning In Multiplicative Situations: Conceptual Analysis, Affordances And Constra1nts. Dissertation .

Ramful, A. (2014). Reversible reasoning in fractional situations: Theorems-in-action and constraints. Journal of Mathematical Behavior, 33, 119130. https://doi.org/10.1016/j.jmathb.2 013.11 .002

Ramful, A. (2015). Reversible reasoning and the working backwards problem solving strategy. Australian Mathematics Teacher, 71(4), 28-32.

Ramful, A., \& Olive, J. (2008). Reversibility of thought: An instance in multiplicative tasks. Journal of Mathematical Behavior, 27(2), 138-151. https://doi.org/10.1016/j.jmathb.2 008.07 .005

Ron Tzur. (2011). Can Dual Processing Theories of Thinking Inform Conceptual Learning in Mathematics? The Mathematics Enthusiast, 8(3), 597-636. Retrieved from http://scholarworks.umt.edu/tme/v ol8/iss3/7\%5Cnhttp://jasonadair.w iki.westga.edu/file/view/Can+Dua 1+Processing+Theories+of+Thinki ng+Inform+Conceptual+Learning +in+Mathematics.pdf/349220092/ Can Dual Processing Theories of Thinking Inform Conceptual Learning

Sangwin, C. J., \& Jones, I. (2017). Asymmetry in student achievement on multiple-choice and constructed-response items in reversible mathematics processes.

Educational Studies in Mathematics, 94(2), 205-222. https://doi.org/10.1007/s10649016-9725-4

Simon, M. A., Kara, M., Placa, N., \& Sandir, H. (2016). Categorizing and promoting reversibility of mathematical concepts. Educational Studies in Mathematics, 93(2), 137-153. https://doi.org/10.1007/s10649. 016-9697-4

Simon, M. A., Placa, N., \& Avitzur, A. 
DOI: https://doi.org/10.24127/ajpm.v10i2.3450

(2016). Participatory and anticipatory stages of mathematical concept learning: Further empirical and theoretical development. Journal for Research in Mathematics Education, 47(1), 63-93. https://doi.org/10.5951/jresemathe duc.47.1.0063

Sriraman, B. (2015). Problem Solving, and the Ability to Formulate Generalizations :, XIV(3), 151165.

Steffe, L. P. (2002). Chapter 1 A New Hypothesis Concerning Children, s Fractional Knowledge. The Journal of Mathematical Behavior, 20(3), 1-12. https://doi.org/10.1007/978-14419-0591-8

Steffe, L. P., \& Olive, J. (2009). Children's fractional knowledge. Springer Science \& Business Media.

Tzur, R. (2004). Teacher and students' joint production of a reversible fraction conception. Journal of Mathematical Behavior, 23(1), 93-114.

https://doi.org/10.1016/j.jmathb.2 003.12 .006

Tzur, R. (2007). Fine grain assessment of students' mathematical understanding: Participatory and anticipatory stagesin learning a new mathematical conception. Educational Studies in Mathematics, 66(3), 273-291. https://doi.org/10.1007/s10649007-9082-4

Tzur, R., \& Simon, M. (2004). Distinguishing two stages of mathematics conceptual learning. International Journal of Science and Mathematics Education, 2(2), 287-304.

https://doi.org/10.1007/s10763-
004-7479-4

Vergnaud, G. (1998). A comprehensive theory of representation for mathematics education. Journal of Mathematical Behavior, 17(2), 167-181.

https://doi.org/10.1016/S03640213(99)80057-3

Yimer, A., \& Ellerton, N. F. (2010). A five-phase model for mathematical problem solving: Identifying synergies in preservice-teachers' metacognitive and cognitive actions. ZDM International Journal on Mathematics Education, 42(2), 245-261. https://doi.org/10.1007/s11858009-0223-3 